\title{
Microbial contaminants cause swelling and inward collapse of yoghurt packs
}

\author{
R Foschino, C Garzaroli, G Ottogalli \\ Department of Food Science and Microbiology, Food and Agricultural Microbiology Section, \\ Via Celoria 2, 20133 Milan, Italy
}

(Received 11 August 1992; accepted 4 February 1993)

\begin{abstract}
Summary - A study was carried out on 10 retail samples of yoghurt, belonging to 3 different brands (, , B and C), showing a rarely described alteration consisting of inward collapse of the packs. Microbiological analyses revealed the presence of high counts of different microbial contaminants: in A samples Acetobacter aceti was found at $10^{7} \mathrm{cfu} / \mathrm{g}$, while in B and C samples the main contaminants were Mucor hiemalis Mucor racemosus and Penicillium verrucosum var cyclopium varying between $10^{2}$ and $10^{5} \mathrm{cfu} / \mathrm{g}$. The responsibility of isolated strains for alteration was confirmed by inoculating cellular suspensions in non-contaminated yoghurt packs kept at $5^{\circ} \mathrm{C}$ and $25^{\circ} \mathrm{C}$ : samples inoculated with $A$ aceti showed an inward collapse after $20 \mathrm{~d}$ at $25^{\circ} \mathrm{C}$; packs inoculated with $M$ hiemalis, $M$ racemosus and $P$ verrucosum var cyclopium kept at $25^{\circ} \mathrm{C}$ showed swelling after $5-7$ d followed by inward collapse after $\approx 20-35 \mathrm{~d}$. In samples kept at $5^{\circ} \mathrm{C}$ the defect did not appear even extending the incubation time to $60 \mathrm{~d}$. The explanation for the evolution of this defect is the following one: contaminating microorganisms consume oxygen contained in head-space of pack and produce $\mathrm{CO}_{2}$ whose re-absorption into the product causes a partial vacuum involving collapse of the pack.
\end{abstract}

\section{yoghurt contamination / yoghurt defect / Acetobacter / Mucor / Penicillium}

Résumé - Contaminants microbiens entraînant le gonflement et le pliage des emballages de yaourts. Dix échantillons de yaourts, appartenant à 3 marques différentes $(A, B$ et $C$ ), ont présenté un type d'accident rarement décrit consistant en un gonflement ou un pliage des emballages.

Les analyses de ces yaourts ont mis en évidence une concentration élevée de divers contaminants microbiens: dans les échantillons $A$ on a trouvé environ $10^{7} \mathrm{ufc} / \mathrm{g} \mathrm{d}^{\prime}$ Acetobacter aceti tandis que les échantillons $B$ et $C$ recélaient entre $10^{2}$ et $10^{5}$ propagules $/ g$ de Mucor hiemalis, Mucor racemosus et Penicillium verrucosum var cyclopium. La responsabilité des souches isolées dans l'apparition des déformations des emballages a été confirmée par inoculation de suspensions cellulaires dans des pots de yaourts et incubation à $5^{\circ} \mathrm{C}$ et $25^{\circ} \mathrm{C}$. Les échantillons contaminés avec $\mathrm{A}$ aceti ont présenté un pliage des emballages après $20 j$ à $25^{\circ} \mathrm{C}$. Ceux inoculés avec $\mathrm{M}$ hiemalis, $\mathrm{M}$ racemosus et $\mathrm{P}$ verrucosum var cyclopium, stockés à $25^{\circ} \mathrm{C}$ ont d'abord gonflé en 5 à $7 \mathrm{j}$, puis se sont pliés en 20 à $35 \mathrm{j}$. De telles déformations ne sont pas apparues dans les échantillons maintenus à $5^{\circ} \mathrm{C}$, même au cours d'une incubation prolongée de $60 \mathrm{j}$. L'évolution des déformations constatée pourrait être due 
au métabolisme des micro-organismes: ils consomment l'oxygène présent dans la partie supérieure des pots et produisent du $\mathrm{CO}_{2}$ dont la réabsorption provoque un vide partiel ayant pour conséquence un pliage des emballages.

contamination yaourt / défaut du yaourt / Acetobacter / Mucor / Penicillium

\section{INTRODUCTION}

Yoghurt defects due to microbial contamination are widely reported in literature; the most frequent contaminants are yeasts and moulds (Suriyarachchi and Fleet, 1981; Garcia and Fernandez, 1984; Fleet and Mian, 1987; Spolaor et al, 1988; Foschino and Ottogalli, 1988) usually causing the swelling of packs, the presence of superficial coloured spots, abnormal tastes (Rasic and Kurmann, 1978; Ottogalli, 1991).

In the present paper we describe a kind of rarely observed alteration (Sutherland et al, 1986) consisting of an inward collapse of yoghurt packs.

The study was focused on the identification of the microorganisms responsible for the spoilage and on the reproduction of the phenomenon in laboratory conditions.

\section{MATERIALS AND METHODS}

\section{Samples}

Analyses were performed on 10 retail samples of yoghurt in 125-g packs (natural and flavoured, whole and skim products), sold in Italy, belonging to 3 different brands ( $A, B$ and $C$ ) utilising different packaging systems (table I).

All the samples examined showed inward collapse within the expiry date; in some samples of brand B the swelling of the packs had preceded the inward collapse.

Non-contaminated samples of plain and flavoured yoghurt free from any microbial contamination were utilized in laboratory tests for controlled inoculations.

\section{Microbiological analysis on retail samples}

The following microbial groups were investigated using the FILIDF standard methods: lactic acid bacteria (FILIDF, 1983); bacterial contaminants (FILIDF, 1971); yeasts and moulds (FIL IDF, 1985).

\section{Identification of microorganisms}

The microbial strains were isolated in specific media and were subsequently identified according to the classical methods referred in literature for bacteria (De Ley et al, 1986), yeasts (Barnett et al, 1983) and moulds (Smith, 1969; Samson et al, 1976).

\section{Reproduction of alteration}

The alterative phenomenon was reproduced inoculating cellular suspensions of pure strains at concentration of $\approx 10^{7}$ colony forming units per gram (cfu/g) in non-contaminated controlled samples of plain and flavoured yoghurt packaged in $125 \mathrm{~g}$ polystyrene cups. The packs were then incubated at $5^{\circ} \mathrm{C}$ and at $25^{\circ} \mathrm{C}$ for a maximum period of $60 \mathrm{~d}$.

Apart from the visual observation of the defect, the following determinations were performed: bacterial contaminants (FILIDF,1971); yeasts and moulds (FILIIDF,1985); D-lactic acid, L-lactic acid, acetic acid and ethanol contents, by spectrophotometric methods utilising enzymatic kits (Boehringer,1984); percent composition of head-space atmosphere by gas chromatographic method (Gas chromatograph PerkinElmer Mod 8500; thermoconductivity detector HWD; column CTR1, 2 m, Alltech Italia). 
RESULTS

\section{Microbiological determinations on retail samples and identification of contaminant microorganisms}

The alteration in all samples consisted of inward collapse observed as a bending of the packs and lids.

The analyses showed the presence of high microbial counts of different types of contaminants in samples from brands A, B and $C$; in brand $A$ samples the bacterial counts reached $10^{7} \mathrm{cfu} / \mathrm{g}$, while in brand $B$ samples the main contaminants were moulds $\left(10^{2}-10^{5} \mathrm{cfu} / \mathrm{g}\right)$ with a lesser content of bacteria; in brand $C$ sample yeasts and moulds reached $10^{6}$ and $10^{5} \mathrm{cfu} / \mathrm{g}$, respectively (table I).

The typical lactic microflora of yoghurt was not influenced by this kind of contaminants.

The bacterial strains isolated from yoghurts of brand $A$ were classified as Acetobacter aceti.
In samples from brand $\mathrm{B}$, moulds were ascribed to species Mucor hiemalis Wehmer, Mucor racemosus Fres and Penicillium verrucosum Dierckx var cyclopium (Westling) Samson et al, and bacteria to genus Bacillus.

In samples from brand $\mathrm{C}$, moulds were ascribed to species $M$ hiemalis and $M$ racemosus and yeasts to species Debaryomyces hansenii (Zopf) Lodder and Kreger-van Rij.

\section{Reproduction of alteration}

Samples inoculated with $A$ aceti showed an inward collapse of the packs after $20 \mathrm{~d}$ at $25^{\circ} \mathrm{C}$, with organoleptic modifications such as browning, sour taste and 'vinegar odour': this was due to high production of acetic acid, while D-lactic acid and Llactic acid did not show important variations (table II); the samples kept at $5^{\circ} \mathrm{C}$ did not show any alterative process for $60 \mathrm{~d}$.

In samples inoculated with $M$ hiemalis, $M$ racemosus and $P$ verrucosum var cyclo-

Table I. Microbiological analyses of retail samples of yoghurt packs showing inward collapse within the expiry date. Standard deviations are indicated.

Analyses microbiologiques des échantillons de yaourt du marché qui montraient le pliage des emballages. Les écarts types sont indiqués.

\begin{tabular}{|c|c|c|c|c|c|c|c|c|}
\hline \multirow{2}{*}{ Branc } & \multirow{2}{*}{$\begin{array}{l}\text { No } \\
\text { samples }\end{array}$} & \multirow[t]{2}{*}{ Pack } & \multirow[t]{2}{*}{ Flavour } & \multirow[t]{2}{*}{ Type } & \multirow{2}{*}{$\begin{array}{l}\text { Lactic flora } \\
\text { (Str + Lact) } \\
\text { cfu/g }\end{array}$} & \multicolumn{3}{|c|}{ Contaminants cfu/g } \\
\hline & & & & & & bacteria & moulds & yeasts \\
\hline A & 4 & $\mathrm{PS}^{\circ}$ & bilberry & whole & $5.4 \times 10^{8} \pm 1.5$ & $2.5 \times 10^{7} \pm 2.0$ & $<10^{2}$ & $<10^{2}$ \\
\hline B & 5 & EPS§ & coconut & whole & $2.1 \times 10^{8} \pm 0.8$ & $3.0 \times 10^{2} \pm 3.9$ & $4.7 \times 10^{4} \pm 5.0$ & $<10^{2}$ \\
\hline C & 1 & $\mathrm{PS}^{\circ}$ & plain & skim & $3.0 \times 10^{6}$ & $<10^{2}$ & $6 \times 10^{5}$ & $2 \times 10^{6}$ \\
\hline
\end{tabular}

- Polystyrene cup; § Expanded polystyrene box.

- Pot en polystyrène; § boîte en polystyrène expansé. 
Table II. Behaviour of yoghurt samples, inoculated with isolated strains, kept at different temperatures. Standard deviations or variation range are indicated.

Comportement des échantillons de yaourt, contaminés avec les souches isolées, maintenus à différentes températures. Les écarts types ou les variations des valeurs sont indiqués.

\begin{tabular}{|c|c|c|c|c|c|c|c|c|c|c|}
\hline $\begin{array}{l}\text { Inoculated } \\
\text { strains }\end{array}$ & $\begin{array}{l}\text { Temp } \\
\left({ }^{\circ} \mathrm{C}\right)\end{array}$ & $\begin{array}{l}\text { Time } \\
\text { (days) }\end{array}$ & $\begin{array}{l}\text { Aspect of } \\
\text { the pack }\end{array}$ & $\begin{array}{l}\text { Microbial } \\
\text { contaminants } \\
\text { cfu/g }\end{array}$ & $\begin{array}{l}\text { Lactic } \\
\text { acid } \\
\text { g/l }\end{array}$ & $\begin{array}{l}\text { Acetic } \\
\text { acid } \\
\text { g/l }\end{array}$ & $\begin{array}{l}\text { Ethanol } \\
\text { g/l }\end{array}$ & $\mathrm{CO}_{2}^{\%}$ & $\begin{array}{l}\text { ad-spac } \\
\text { mpositi } \\
\mathrm{O}_{2}\end{array}$ & $\mathrm{~N}_{2}$ \\
\hline $\begin{array}{l}\text { Acetobacter } \\
\text { aceti }\end{array}$ & 25 & $\begin{array}{l}0 \\
20\end{array}$ & $\begin{array}{l}\text { normal } \\
\text { ic }\end{array}$ & $\begin{array}{l}1.0 \times 10^{5} \\
2.2 \times 10^{8} \pm 1.7\end{array}$ & $\begin{array}{l}8.2-9.6 \\
6.7-9.3\end{array}$ & $\begin{array}{c}0.1-0.7 \\
20.7-40.4\end{array}$ & & $\begin{array}{l}\text { nd } \\
\text { nd }\end{array}$ & $\begin{array}{l}\text { nd } \\
\text { nd }\end{array}$ & $\begin{array}{l}\text { nd } \\
\text { nd }\end{array}$ \\
\hline $\begin{array}{l}\text { Mucor } \\
\text { hiemalis }\end{array}$ & 25 & $\begin{array}{l}0 \\
5-7 \\
19-20 \\
0 \\
19\end{array}$ & $\begin{array}{l}\text { normal } \\
\text { swollen } \\
\text { ic } \\
\text { normal } \\
\text { swollen }\end{array}$ & $\begin{array}{l}2.5 \times 10^{5} \pm 2.1 \\
3.5 \times 10^{5} \pm 3.5 \\
2.5 \times 10^{4} \pm 0.7 \\
2.0 \times 10^{5} \\
5.0 \times 10^{3}\end{array}$ & $\begin{array}{l}10.7-14.3 \\
12.0-15.0 \\
10.2-15.0 \\
12.0 \\
12.0\end{array}$ & & $\begin{array}{l}<0.1 \\
4.0-5.0 \\
8.1-23.3 \\
<0.1 \\
3.0\end{array}$ & $\begin{array}{r}1.2 \\
75.4 \\
19.6 \\
1.5 \\
62.4\end{array}$ & $\begin{array}{r}18.5 \\
0.4 \\
11.2 \\
18.0 \\
0.5\end{array}$ & $\begin{array}{l}80.3 \\
24.2 \\
69.2 \\
80.5 \\
37.1\end{array}$ \\
\hline $\begin{array}{l}\text { Mucor } \\
\text { racemosus }\end{array}$ & 5 & $\begin{array}{l}0 \\
5-7 \\
20-33 \\
0 \\
26\end{array}$ & $\begin{array}{l}\text { normal } \\
\text { swollen } \\
\text { ic } \\
\text { normal } \\
\text { swollen }\end{array}$ & $\begin{array}{l}9.5 \times 10^{4} \pm 0.7 \\
1.0 \times 10^{4} \\
2.5 \times 10^{3} \pm 2.1 \\
1.0 \times 10^{4} \\
5.0 \times 10^{3}\end{array}$ & $\begin{array}{r}10.7-14.8 \\
9.7-18.8 \\
10.2-16.5 \\
12.0 \\
13.5\end{array}$ & & $\begin{array}{l}<0.1 \\
2.5-3.5 \\
7.2-20.0 \\
<0.1 \\
2.5\end{array}$ & $\begin{array}{r}1.2 \\
74.4 \\
31.3 \\
1.5 \\
59.8\end{array}$ & $\begin{array}{r}18.7 \\
0.3 \\
4.7 \\
18.0 \\
1.2\end{array}$ & $\begin{array}{l}80.1 \\
25.3 \\
64.0 \\
80.5 \\
39.0\end{array}$ \\
\hline $\begin{array}{l}\text { Penicillium } \\
\text { verrucosum } \\
\text { cyclopium }\end{array}$ & 25 & $\begin{array}{l}0 \\
7 \\
35\end{array}$ & $\begin{array}{l}\text { normal } \\
\text { swollen } \\
\text { ic }\end{array}$ & $\begin{array}{l}4.0 \times 10^{5} \\
1.0 \times 10^{4} \\
1.0 \times 10^{3}\end{array}$ & $\begin{array}{l}13.0-13.8 \\
12.3-12.9 \\
11.2-12.3\end{array}$ & & $\begin{array}{l}<0.1 \\
<0.1 \\
<0.1\end{array}$ & $\begin{array}{r}1.2 \\
74.5 \\
28.5\end{array}$ & $\begin{array}{r}18.8 \\
0.5 \\
5.7\end{array}$ & $\begin{array}{l}80.0 \\
25.0 \\
65.8\end{array}$ \\
\hline
\end{tabular}

ic: inward collapsed 
pium kept at $25^{\circ} \mathrm{C}$ swelling of the packs occurred within 5-7 d followed by inward collapse (fig 1) after $\approx 20-35 \mathrm{~d}$; in samples kept at $5^{\circ} \mathrm{C}$ the swelling occurred after $\approx 20-30 \mathrm{~d}$ (table II) only in packs contaminated with $M$ hiemalis and $M$ racemosus, but the inward collapse did not appear even when the incubation time was extended to $60 \mathrm{~d}$.

Samples contaminated with Bacillus spp and $D$ hansenii did not show any modification of packs kept at both temperatures.

During the swelling phase, samples contaminated with moulds showed significant changes of head-space composition which began with a strong increase of $\mathrm{CO}_{2}$, followed by a $\mathrm{CO}_{2}$ drop during the inward collapse phase.

In samples inoculated with strains of moulds belonging to $M$ hiemalis and $M$ racemosus production of ethanol was observed.

\section{DISCUSSION}

Inward collapse of packs is a rare type of alteration which has practically not been reported in the literature; in this paper we have described some different cases of this defect due to microbial contaminants.

The microorganisms responsible for this alteration can be either bacteria belonging to Acetobacter, or moulds belonging to $\mathrm{Mu}$ cor or Penicillium; Bacillus and Debaryomyces, which were also found in spoiled yoghurts, cannot be considered responsible since they were unable to reproduce the phenomenon in our laboratory tests.

The development of such defect can be attributed to:

- microbial contamination of the product by strains able to grow at low $\mathrm{pH}$ and provided with an oxidising respiratory metabolism;

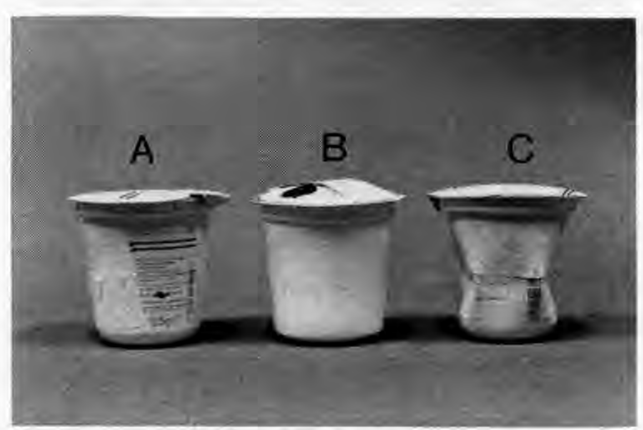

Fig 1. Non-contaminated pack (A); swollen pack (B); and pack showing inward collapse (C).

Emballage sans défaut (A), emballage gonflé (B) et emballage plié (C).

- consumption of head-space oxygen by the above-mentioned microorganisms with $\mathrm{CO}_{2}$ production;

- re-absorption of $\mathrm{CO}_{2}$ into the product with a subsequent partial vacuum causing collapse of the pack.

Strict observance of good manufacturing practices and correct conditions of refrigeration constitute the best means of avoiding or slowing down this kind of alterations.

\section{REFERENCES}

Barnett JA, Payne RW, Yarrow D (1983) Yeasts. Characteristics and Identification. Cambridge Univ Press, Cambridge

Boehringer Mannheim Biochem (1984) Methods of Enzymatic Food Analysis. BoehringerMannheim

De Ley J, Gillis M, Swings J (1986) Family VI. Acetobacteraceae. In: Bergey's Manual of Systematic Bacteriology (Krieg NR, Holt JG, eds) Williams and Wilkins Co, Baltimore, vol 1

FILIDF (1971) Fermented Milks: Count of Microbial Contaminants. Int Stand No 66 
FILIDF (1983) Yoghurt - Characteristic Microorganisms. Int Stand No 117

FILIDF (1985) Milk and Milk Products. Detection and Enumeration of Yeasts and Moulds. Int Stand No 94A

Fleet GH, Mian MA (1987) The occurrence and growth of yeasts in dairy products. Int J Food Microbiol 4, 145-155

Foschino R, Ottogalli G (1988) Episodio di bombaggio in yogurt ai cereali causato da muffe del genere Mucor. Ann Microbiol Enzimol 38, 147-153

Garcia AM, Fernandez GS (1984) Contaminating mycoflora in yogurt: general aspects and special reference to the genus Penicillium. $J$ Food Prot 47, 629-636

Ottogalli G (1991) I latti fermentati. In: Microbiologia Lattiero-casearia. I prodotti. 123-146. CLESAV CittàStudi, Milan, vol 2
Rasic JL, Kurmann JA (1978) Defects of yoghurts. In: Yoghurt. (Rasic JL, Kurmann JA, eds) Tech Dairy Publ House, Copenhagen 297-302

Samson RA, Stolk AC, Hadlok R (1976) Revision of the subsection Fasciculata of Penicillium and some allied species. Stud Mycol 11, 47

Smith G (1969) Zygomycetes. In: An Introduction to Industrial Mycology (Smith G, ed) Edward Arnold Ltd, London, 28-43

Spolaor D, Zilio F, Dal Santo ML, Cavallari A, Restello I, Zanatta P, Loddo A, Giacon D, Broggiato F (1988) Caratterizzazione microbiologica dello yogurt. Latte 13, 1085-1097

Suriyarachchi VR, Fleet GH (1981) Occurrence and growth of yeasts in yogurts. J Appl Environ Microbiol 42, 574-579

Sutherland JP, Varnam AH, Evans MG (1986) Dairy. In: A Colour Atlas of Food Quality Control. Wolfe Publ Ltd, London, 16-46 